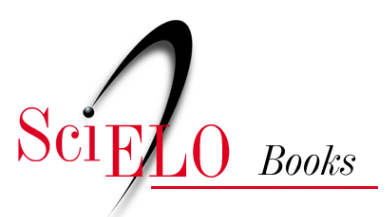

\title{
24 Tribo Tageteae Cass.
}

\author{
João Bernardo de A. Bringel Jr. \\ Maria Alves \\ Mara Angelina Galvão Magenta
}

BRINGEL JR., J.B.A., ALVES, M., and MAGENTA, M.A.G. Tribo Tageteae Cass. In: ROQUE, N. TELES, A.M., and NAKAJIMA, J.N., comp. A família Asteraceae no Brasil: classificação e diversidade [online]. Salvador: EDUFBA, 2017, pp. 175-179. ISBN: 978-85-232-1999-4.

https://doi.org/10.7476/9788523219994.0026.

All the contents of this work, except where otherwise noted, is licensed under a Creative Commons Attribution 4.0 International license.

Todo o conteúdo deste trabalho, exceto quando houver ressalva, é publicado sob a licença Creative Commons Atribição $\underline{4.0}$.

Todo el contenido de esta obra, excepto donde se indique lo contrario, está bajo licencia de la licencia Creative Commons Reconocimento 4.0. 


\title{
TRIBO TAGETEAE CASS.
}

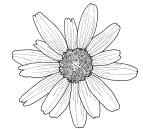 \\ João Bernardo de A. Bringel Jr. \\ Maria Alves \\ Mara Angelina Galvão Magenta
}

Embora Tageteae seja uma tribo reconhecida desde a época de Cassini (1819), alguns tratamentos taxonômicos, com base em características morfológicas e micromorfológicas (KARIS; RYDING, 1994; ROBINSON, 1981), divergiram quanto ao reconhecimento do grupo como tribo. Mesmo assim, esses autores mantiveram a ideia de que Tageteae seria um grupo natural, já que a maioria dos gêneros atualmente reconhecidos para a tribo estava inserida na subtribo Pectidinae de Heliantheae (ROBINSON, 1981) ou em Helenieae (KARIS; RYDING, 1994). Somente a partir das filogenias com base em dados moleculares de DNA nuclear ribossomal (BALDWIN; WESSA; PANERO, 2002) e de cloroplasto (PANERO; FUNK, 2002), a aceitação de Tageteae como tribo distinta foi consolidada.

A presença de cavidades secretoras (chamadas por alguns autores de glândulas pelúcidas) nas folhas e brácteas involucrais era uma característica comumente utilizada para reconhecer Tageteae (ou Pectidinae) (BARROSO et al., 1991; ROBINSON, 1981; STROTHER, 1977). No entanto, dados moleculares em estudos filogenéticos (BALDWIN; WESSA; PANERO, 2002) indicaram, embora com suporte estatístico não muito robusto, que a circunscrição da tribo deveria ser expandida, o que englobaria gêneros que não apresentam tais características. Os gêneros atualmente inseridos em Tageteae que não apresentam cavidades secretoras ou glândulas podem, em sua maioria, ser reconhecidos por apresentarem apêndice basal das anteras glabro, fortemente esclerificado, cipselas estriadas com carpopódio 
bem desenvolvido e, geralmente, pápus formado por cerdas ou escamas livres (PANERO, 2007).

Atualmente, Tageteae apresenta 32 gêneros e aproximadamente 270 espécies (BALDWIN, 2009; PANERO, 2007). Ocorre de forma predominante no México e porção sudoeste dos Estados Unidos, com representantes também na América do Sul e Caribe (BALDWIN, 2009, PANERO, 2007).

\section{Descrição}

Ervas a arbustos, raramente arvoretas, monoicas ou ginomonoicas. Folhas inteiras, pinadas ou bipinadas, alternas ou opostas, margem frequentemente com cavidade secretora (glândulas pelúcidas). Capitulescência cimosa, às vezes paniculiforme ou capítulos solitários. Capítulos geralmente radiados ou, de forma menos frequente, discoides; brácteas involucrais 1-4 séries, subiguais a gradativamente desiguais, livres ou conatas, frequentemente (apenas em Pectidinae) com cavidades secretoras ou glândulas infladas, às vezes com calículo 1-seriado; receptáculo plano ou cônico, epaleáceo ou raramente com pequenas escamas, cerdas ou faveolado. Flores do raio, quando presentes, pistiladas; flores do disco bissexuais, raramente funcionalmente estaminadas; corola actinomorfa, raramente zigomorfa, 5 lobos, raramente 4 ou 6 lobos; antera com apêndice do conectivo oval, deltoide, lanceolado ou inconspícuo, geralmente glabro e esclerificado, células do endotécio com espessamento polarizado, 0-2, 2-4 ou radialmente espessadas; ramos do estilete com ápice agudo ou atenuado, às vezes arredondado (em Pectis), linhas estigmáticas geralmente não confluentes no ápice, apêndices estéreis presentes ou não. Cipselas enegrecidas ou raramente marrons, cilíndricas a estreito-fusiformes ou piramidais, raramente comprimidas, estriadas, variadamente pubescentes; pápus formado por cerdas e/ou escamas livres, ocasionalmente escamas formando uma reduzida estrutura coroniforme, ou pápus ausente.

No Brasil, são encontrados 5 gêneros e 30 espécies: Flaveria Juss. (Flaveriinae), Jaumea Pers. (Jaumeinae), Pectis L., Porophyllum Guett. (Figuras 19A-B) e Tagetes L. (Figura 19C) (Pectidinae). 


\section{Chave de identificação para os gêneros de Tageteae no Brasil}

1. Plantas sem cavidades secretoras nas folhas e brácteas involucrais ....... 2 1'. Plantas com cavidades secretoras nas folhas ou nas brácteas involucrais

2. Capitulescência com capítulos discoides e radiados, frequentemente com apenas uma flor do raio; brácteas involucrais em 2 séries Flaveria 2'. Capitulescências apenas com capítulos discoides; brácteas involucrais em 3-4 séries Jaumea

3. Lâmina foliar com cerdas setosas nas margens; apêndice do conectivo da antera truncado; ramos do estilete curtos, de ápice arredondado ....... Pectis 3'. Lâmina foliar desprovida de cerdas nas margens; apêndice do conectivo da antera oval a lanceolado; ramos do estilete longos, de ápice agudo ou acuminado 4

4. Lâmina foliar geralmente pinatissecta; pápus formado por escamas (Figura 17G) Tagetes 4'. Lâmina foliar inteira; pápus formado por cerdas (Figura 17H)

Porophyllum

\section{Literatura Recomendada}

BALDWIN, B. G. Heliantheae alliance. In: FUNK, V. A. et al. Systematics, Evolution and Biogeography of Compositae. Vienna: IAPT, 2009. Chapt. 41, p. 689-711.

BALDWIN, B. G.; WESSA, B. L.; PANERO, J. L. Nuclear rDNA evidence for major lineages of helenoid Heliantheae. Systematic Botany, Kent, v. 27, n. 1, p. 161-198, 2002.

BARROSO, G. M. et al. Sistemática de angiospermas do Brasil. Viçosa: UFV, 1991. v. 3. 
BAUTISTA, H. P. Pectis L. (Compositae-Tageteae). Espécies ocorrentes no Brasil. Arquivos do Jardim Botânico do Rio de Janeiro, Rio de Janeiro, v. 28, p. 20-107, 1987.

CARNEIRO, C. R. As tribos Helenieae Benth \& Hook., sensu stricto, e Tageteae Cass., sensu lato, (Asteraceae) no Sul do Brasil. 2014. Dissertação (Mestrado em Botânica ) - Instituto de Biociências, Universidade Federal do Rio Grande do Sul, Porto Alegre, 2014.

CASSINI, H. Suit du Sixième mémoire sur la famille des Synanthérées, contenant les caractères des tribus. Journal de Physique, de Chimie, d'Histoire Naturelle et des Arts, Paris, t. 88, p. 150-163, 1819.

CORDAZZO, C. V.; CAETANO, V. L.; COSTA, C. S. B. Jaumea linearifolia (Juss.) DC. (Asteraceae), primeiro registro para o Brasil. Theringia, Porto Alegre, v. 62, n. 1/2, p. 99-102, 2007. Série Botânica.

HIND, D. J. N. A New species of Porophyllum (Compositae: Heliantheae) from Bahia, Brazil. Kew Bulletin, London, v. 57, n. 3, p. 705-709, 2002.

JOHNSON, R. R. Monograph of the plant genus Porophyllum (Compositae: Helenieae). The Universit of Kansas Science Bulletin, Lawrence, v. 48, n. 7, p. 225-267, 1969.

KARIS, P. O.; RYDING, O. Tribe Helenieae. In: BREMER, K. (Ed.). Asteraceae: cladistics and classification. Portland: Timber Press, 1994. p. 521-558.

PANERO, J. L. Tribe Tageteae Cass. In: KUBITZKI, K. (Ed.). The Families and Genera of Vascular Plant: v. VIII: Flowering Plants Eudicots: Asterales. Berlin: Springer-Verlag, 2007. p. 421-431.

PANERO, J. L.; FUNK, V. A. Toward a phylogenetic subfamilial classification for the Compositae (Asteraceae). Proceedings of the Biological Society of Washington, Washington, v. 115, n. 4, p. 909-922, 2002.

POWELL, A. M. Systematics of Flaveria (Flaveriinae-Asteraceae). Annals of the Missouri Botanical Garden, Saint Louis, v. 65, p. 590-636, 1978. 
ROBINSON, H. A revision of the tribal and subtribal limits of the Heliantheae (Asteraceae). Washington: Smithsonian Institution Press, 1981.

(Smithsonian Contributions to Botany, v. 51).

SOULE, J. Systematics of Tagetes (Asteraceae-Tageteae). 1993. 781 1. Thesis $(\mathrm{PhD})$ - University of Texas, Austin, 1993. $2 \mathrm{v}$.

STROTHER, J. L. Tageteae-systematic review. In: HEYWOOD, V. H.;

HARBONE, J. B.; TURNER, B. L. (Ed.). The Biology and Chemestry of the

Composite London: Academic Press, 1977.. v. 2. p. 769-783. 